\title{
МІЖНАРОДНИЙ ТА ВІТЧИЗНЯНИЙ ДОСВІД РОЗВИТКУ ФОРМАТУ «АРТ-КАФЕ»: ОСОБЛИВОСТІ, ТЕНДЕНЦІї, ФАКТОРИ УСПІХУ.
}

\author{
МЕЖДУНАРОДНЫЙ И ОТЕЧЕСТВЕННЫЙ ОПЫТ РАЗВИТИЯ ФОРМАТА «АРТ- \\ КАФЕ»: ОСОБЕННОСТИ, ТЕНДЕНЦИИ, ФАКТОРЫ УСПЕХА
}

\section{INTERNATIONAL AND DOMESTIC EXPERIENCE OF" ART CAFE " EVOLUTION: FEATURES AND TRENDS, SUCCESS FACTORS}

Дану роботу присвячено дослідженню міжнародної практики діяльності закладів ресторанно-розважального бізнесу формату арт-кафе. Мета роботи - сформувати розуміння ідеї, філософії та особливостей даного формату закладів в різних краӥнах світу, та запропонувати рекомендації з адаптації даного формату закладів до сучасних умов на вітчизняному ринку. Активний розвиток ресторанного бізнесу в категорії арт-кафе в Україні та світі було започатковано ще в 20-х роках XX століття. Сьогодні ией формат закладів поновлює свою популярність на вітчизняному ринку. Проте, лише іноді такій модній нині назві «арт-кафе» відповідає ідея, концепція та облаштування самого закладу. Це призводить до знищення вигідної ринкової диференціації даного формату закладів та, відповідно, суттєво змениує його споживчу иінність. Підприємщі, які працюють у даній сфері не виділяють конкретних рамок та систем, за якими має працювати арт-кафе, але прослідковується наявність певних схожих рис та приничипів роботи. В дослідженні робиться спроба дослідити иңю специффіку, вітчизняний та світових досвід $і$ запропонувати практичні рекомендачії з проектування та реалізації закладів типу арт-кафе.

Ключові слова: кафе, арт-кафе, тайм-кафе, особливості арт-кафе, цінності арт-кафе, міжнародний досвід, концепція успіху.

Данную работу посвящено исследованию международной практики деятельности учреждений ресторанно-развлекательного бизнеса формата арт-кафе. Цель работь сформировать понимание идеи, философии и особенностей данного формата заведений в разных странах мира, и предложить рекомендации по адаптации данного формата заведений в современных условиях на отечественном рынке. Активное развитие ресторанного бизнеса в категории арт-кафе в Украине и мире началось еще в 20-х годах XX века. Сегодня этот формат заведений возобновляет свою популярность на отечественном рынке. Однако, лишь иногда такому модному сейчас названию «арт-кафе» соответствует идея, концепџия и обустройство самого заведения. Это приводит к уничтожению выгодной рыночной дифференциичии данного формата заведений и, соответственно, существенно уменьшает его потребительскую ценность. Предприниматели, работающие в данной сфере не выделяют конкретных рамок и систем, с которыми работать арт-кафе, но прослеживается наличие определенных схожих черт и принщипов работы. В исследовании делается попытка исследовать эту специифику, отечественный и мировой опыт $u$ предложить практические рекомендации по проектированию и реализации заведений типа apm-кафе.

Ключевые слова: кафе, арт-кафе, тайм-кафе, особенности арт-кафе, ценности арткафе, международный опыт, концепция успеха 
This essay is devoted to research of international experience in restaurant and entertainment businesses, such as a type of establishments - art-cafe. The objective of the essay is to form an understanding of ideas, philosophy and characteristics of the business in different countries, with the aim of art-cafe projects successful adaptation in the domestic market. Active development of the restaurant business in the category of art-cafe in Ukraine and the world started in 20-ies. Today this format institutions reiterates its popularity in the domestic market. However, sometimes this just now fashionable name of "art-cafe" corresponds to the idea, the concept and construction of the institution. This leads to the destruction of the lucrative market differentiation format institutions and therefore significantly reduces its consumer value. Entrepreneurs working in this area do not allocate specific frameworks and systems, which has run an art cafe, but there are some evident similarities and operating principles. The study attempts to examine specific, local and international experience and offer practical advice on designing and implementing institutions such art-cafe.

Keywords: cafe, art-cafe, time-cafe, features of art-cafe, values of art-cafe, international experience, the concept of success.

Вступ. Розвиток ресторанно-розважального бізнесу як на світовому, так i вітчизняному рівнях є достатньо потужним, ринок зростає швидкими темпами, i викликає потребу в створенні закладів, які будуть надавати послуги нового якісного рівня, матимуть різностороннє спрямування та задовольнятимуть широкий ряд цінностей споживачів. Саме таким типом закладів даної сфери бізнесу може стати формат арт-кафе.

Міжнародний досвід розвитку формату арт-кафе показує, що у кожній країні ця категорія закладів розвивалась у різний час і зі своєю специфікою. В одних країнах (США, Велика Британія, Австралія та ін.) - це вже давно популярний бізнес, у інших - інноваційні ідеї, що перебувають на етапі зародження (в статусі startup проектів) чи тільки набирають розвитку. На території більшості країн Азії та Африки - арт-кафе досі нерозвинений сектор ринку, хоча для цього $є$ потенціал та необхідні ресурси. Але, загальною тенденцією $є$ те, що не зважаючи на відмінності країн, їхніх споживчих та національних культур, заклади арт-кафе майже по всьому світі набирають своєї популярності.

3 метою кращого розуміння ідеї та філософії закладів формату арт-кафе вивчимо міжнародний досвід та сучасні тенденції характерні для різних країн світу. В нашому досліджені випадковим чином за допомогою Інтернет ресурсу GoogleMaps відібрано та проаналізовано по три заклади формату арт-кафе у таких країнах як: Америка, Велика Британія, Нідерланди, Австралія. Ці країни відібрані для ретельного дослідження через те, що заклади арт-кафе там давно усталені, популярні та успішно діють.

Постановка проблеми. Активний розвиток ресторанного бізнесу в категорії арт-кафе в Україні та світі було започатковано ще в 20-х роках XX століття. Сьогодні цей формат закладів поновлює свою популярність на вітчизняному ринку. Проте, лише іноді такій модній нині назві «арт-кафе» відповідає ідея, концепція та облаштування самого закладу. Це призводить до знищення вигідної ринкової диференціації даного формату закладів та, відповідно, суттєво зменшує його споживчу цінність. 
Дана проблема є нагальною, оскільки запозичені з-за кордону сучасні бізнес-ідеї важливо коректно адаптувати до вітчизняних умов зберігаючи i примножуючи їх ринкову цінність.

Метою даної статті є спроба дослідити міжнародну практику у форматі закладів арт-кафе для формування кращого розуміння ідеї, філософії та особливостей кафе даного типу, визначення факторів їх ринкового успіху та адаптації закордонного досвіду у вітчизняні реалії.

Методологія. Інформаційною базою даної роботи стали вітчизняні та міжнародні галузеві огляди, галузеві класифікатори, веб-сайти підприємств досліджуваної галузі, словники, результати власних досліджень авторів.

Для реалізації поставлених завдань застосовано ряд методів, зокрема аналіз і синтез, загальнонаукові методи, методи систематизації, порівнянь, спостереження, абстрактно-логічний метод для узагальнення результатів дослідження і формулювання висновків.

Результати дослідження. Досліджуючи історичну еволюцію послуги арт-кафе в світі можна зазначити що, значення поняття «арт-кафе» сприймається та декодується бізнесменами та споживачами по-різному. «Art» (у перекладі 3 англійської означає «мистецтво») та «саfe» (у перекладі 3 французької буквально - «кава» - в найзагальнішому значенні - заклад громадського харчування та відпочинку. Також відіграють значну роль відмінності країн та менталітету людей.

Заклади формату арт-кафе стали популярними в Свропі на початку XX століття й доволі швидко почали розповсюджуватись в інших регіонах. Перший заклад такого типу, а саме дискусійний центр для літераторів та філософів 3’явився у 18 столітті в Австрії під назвою «Bellevue». Більшість концерт-кафе, заснованих того часу, знаходились у парку району Вени - Леопольдштат (у минулому імперські ділянки землі для полювання), які були відкриті для широкої публіки під назвою Пратер. У Пратері було відкрито «Перше кафе», «Друге кафе» $\mathrm{i}$ «Третє кафе», цим закладам було характерно мати в центрі зали велику сцену, де виступали відомі музиканти. Людвиг ван Бетховен, Йозеф Ланнер, Іоанн Штраус та Карл 3’ єхрер виконували для гостей свої твори.

До сучасних днів такі кафе зазнали значних змін та набули нового формату й цільової аудиторії в більшій мірі залишивши за собою початкову ідею творчості, мистецтва та культури.

В Україні перший заклад схожого типу було відкрито в Києві в 1918 році під назвою «Х.Л.А.М.» у статусі літературно-артистичного клубу в готелі «Континенталь». Його назва $\epsilon$ абревіатурою перших букв назв творчих професій: художники, літератори, артисти, музиканти.

Історично, арт-кафе - це свого роду клуб за інтересами, в якому збираються люди зі схожими поглядами в музиці, живописі та інших видах мистецтва. Особлива увага приділяється тому, як відвідувачі проводять там свій час - перегляд кінофільмів, виставки, інтелектуальні ігри, концерти тощо.

Дослідження показало, що, як в Україні так і в світі існує ряд закладів ресторанного бізнесу, які позиціонуються як арт-кафе не відповідаючи зазначеному вище критерію. Серед цих закладів є паби, бари, класичні кафе. 
Порівняння різних форматів кафе наведемо в таблиці.

Таблиця 1

\section{Порівняльна характеристика форматів кафе}

\begin{tabular}{|c|c|c|c|}
\hline \multirow{8}{*}{$\frac{2 N o}{1}$} & Тип закладу & Характеристика закл & \\
\hline & \multirow[t]{7}{*}{$\begin{array}{l}\text { Кафе } \\
\text { (класичне) }\end{array}$} & \multicolumn{2}{|c|}{ 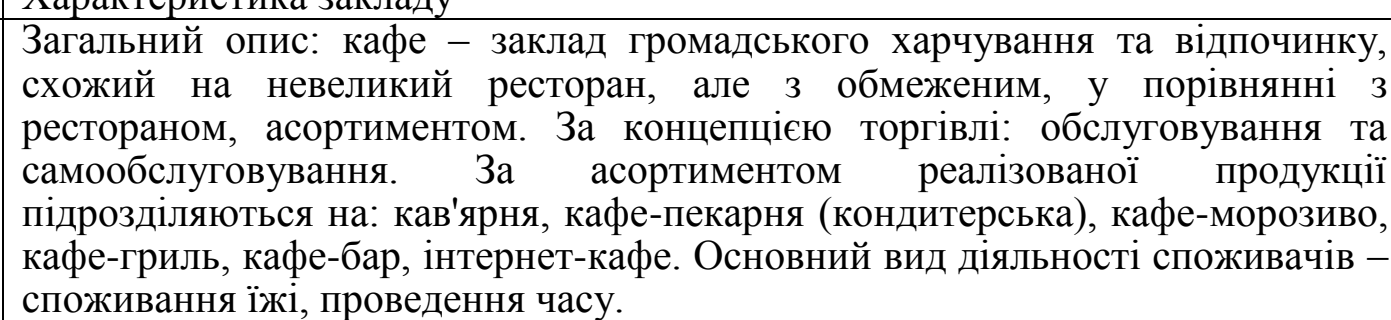 } \\
\hline & & 1. Меню та & $\begin{array}{l}\text { Меню та послуги кафе залежать від його категорії (за } \\
\text { типом кухні (японська, італійська, етнічна т.д.), за } \\
\text { специфікою їжі (спеціалізація на каві, страви з } \\
\text { картоплі, шоколадні десерти тощо). Меню може бути } \\
\text { як з широким, так і з вузьким асортиментом. } \\
\text { Постійна, розважальна програма відсутня. Зазвичай є } \\
\text { доступ в Інтернет через Wi-Fi. }\end{array}$ \\
\hline & & $\begin{array}{l}\text { 2. Цільова } \\
\text { аудиторія }\end{array}$ & $\begin{array}{l}\text { Чоловіки та жінки усіх вікових груп. Рівень заробітку } \\
\text { - середній, високий. Відвідують кафе на обідніх } \\
\text { перервах, у свята, під час вихідних прогулянок. Кафе } \\
\text { відвідують для проведення побачень, відпочинку з } \\
\text { друзями, роботи. }\end{array}$ \\
\hline & & 3. Цінова політика & $\begin{array}{l}\text { Оплачуються замовлені страви. Цінова політика } \\
\text { залежить від специфіки та класу закладу. }\end{array}$ \\
\hline & & $\begin{array}{l}\text { 4. Місце } \\
\text { знаходження }\end{array}$ & $\begin{array}{l}\text { Стаціонарні - в окремих будівлях, частіше всередині } \\
\text { (на перших поверхах) або ж прибудови до них; } \\
\text { Вуличні - в окремих будівлях чи біля доріг; Сезонні } \\
\text { кафе - біля моря, річки, гір тощо; Кафе на відкритому } \\
\text { повітрі - з виносними столами та стільцями. }\end{array}$ \\
\hline & & $\begin{array}{l}\text { 5. Iнтер'єр/ } \\
\text { екстер'єр } \\
\text { (дизайн) }\end{array}$ & \multirow{2}{*}{$\begin{array}{l}\text { Залежать від концепції закладу, ЦА, цінової політики. } \\
\text { Створюється і відповідна атмосфера (діловий стиль, } \\
\text { романтичний, тематичного спрямування тощо). }\end{array}$} \\
\hline & & $\begin{array}{l}\text { 6. Загальна } \\
\text { атмосфера }\end{array}$ & \\
\hline \multirow[t]{3}{*}{2} & \multirow[t]{3}{*}{$\begin{array}{l}\text { Анти-кафе } \\
\text { (також } \\
\text { вільний } \\
\text { простір, } \\
\text { тайм-клуб, } \\
\text { тайм-кафе) }\end{array}$} & \multicolumn{2}{|c|}{$\begin{array}{l}\text { Загальний опис: анти-кафе - тип громадських закладів соціального } \\
\text { спрямування, основною характеристикою є оплата, в першу чергу, за } \\
\text { проведений час. Відвідувачі мають більше свободи, ніж в класичних кафе } \\
\text { або ресторані. Зазвичай, в анти-кафе існує зона пригощань, де відвідувачі } \\
\text { можуть зробити собі чай, каву, взяти солодощі (можна приносити свою } \\
\text { іжу). Як правило, алкоголь та куріння заборонені. } \\
\text { Основний вид діяльності відвідувачів - приємне проведення часу, розваги } \\
\text { та відвідування заходів. За концепцією торгівлі: самообслуговування. }\end{array}$} \\
\hline & & $\begin{array}{l}\text { 1. Послуги/ } \\
\text { товари }\end{array}$ & $\begin{array}{l}\text { Широкий вибір настільних } \\
\text { (комп’ютерних)/інтелектуальних ігор } \\
\text { (влаштування змагань); організація заходів; здача } \\
\text { залу в оренду; меню (з вузьким асортиментом їжі } \\
\text { та напоїв). } \\
\text { Багато анти-кафе роблять акцент на настільних і } \\
\text { відеоіграх або робочій атмосфері коворкінгу. } \\
\text { Зазвичай є доступ в Інтернет через Wi-Fi. Часто, } \\
\text { тайм-кафе має специфічну спрямованість у } \\
\text { діяльності: робочий простір, креативний простір, } \\
\text { інтелектуальний простір і т.д. }\end{array}$ \\
\hline & & 2. ЦА & Чоловіки та жінки віком від 16 до 30 (молодь). \\
\hline
\end{tabular}




\begin{tabular}{|c|c|c|c|}
\hline & & & $\begin{array}{l}\text { Рівень заробітку низький-середній. Відвідують } \\
\text { анти-кафе після навчання/роботи } 3 \text { друзями для } \\
\text { спілкування, ігор, навчання, роботи. }\end{array}$ \\
\hline & & 3. Цінова політика & $\begin{array}{l}\text { В анти-кафе оплачується тільки час перебування } \\
\text { в закладі (наприклад, щохвилини або } \\
\text { погодинно).У вартість входить оплата за меню } \\
\text { (чай/кава/печиво), відвідування заходу, } \\
\text { користуванням простором та матеріалами анти- } \\
\text { кафе. }\end{array}$ \\
\hline & & 4. Місце знаходження & $\begin{array}{l}\text { Анти-кафе розташовують за межею центру міста, } \\
\text { поблизу цільової аудиторії (студентські містечка), } \\
\text { біля освітніх закладів. }\end{array}$ \\
\hline & & $\begin{array}{l}\text { 5. Інтер’єр/ } \\
\text { екстер'єр(дизайн) }\end{array}$ & $\begin{array}{l}\text { Як правило, анти-кафе являє собою один великий } \\
\text { зал або кілька кімнат із затишним, простим } \\
\text { інтер'єром, в якому відвідувачі вільно } \\
\text { переміщаються (на обстановку не витрачається } \\
\text { багато коштів). }\end{array}$ \\
\hline & & 6. Загальна атмосфера & $\begin{array}{l}\text { Атмосфера домашнього затишку, спокійна, } \\
\text { налаштовує як на активний час проведення, так i } \\
\text { на роботу. }\end{array}$ \\
\hline 3 & Арт-кафе & $\begin{array}{l}\text { Загальний опис: арт-1 } \\
\text { збираються люди зі схо } \\
\text { мистецтва. Арт-кафе, ч } \\
\text { певну тематику: здоро } \\
\text { соціально-культурного } \\
\text { обслуговування або сам }\end{array}$ & $\begin{array}{l}\text { фе свого роду клуб за інтересами, в якому } \\
\text { ими поглядами в живописі, музиці та інших видах } \\
\text { сто, окрім концепції просування мистецтва мають } \\
\text { їжа, етнічність і т.д. Таке кафе, часто, набуває } \\
\text { начення (галерея, клуб). За концепцією торгівлі: } \\
\text { обслуговування. }\end{array}$ \\
\hline & & $\begin{array}{l}\text { 1. Послуги/ } \\
\text { товари }\end{array}$ & $\begin{array}{l}\text { Асортимент меню середній між класичним кафе } \\
\text { та тайм-кафе (зазвичай широкий вибір холодних } \\
\text { та гарячих напоїв, десертів та свіжої випічки, } \\
\text { страв швидкого приготування (багети, сандвічі, } \\
\text { конусна піца тощо)). Особлива увага } \\
\text { приділяється розважальній програмі: організація } \\
\text { різнотипних заходів арт-спрямування: художні, } \\
\text { музичні, театральні вечори (відвідувачі можуть } \\
\text { не лише споглядати, але й брати участь), майстер- } \\
\text { класи, тренінги, виставки і т.д. (акцент ставиться } \\
\text { на унікальність заходів), арт-складова вирізняє } \\
\text { даний тип кафе серед інших. Послуга оренди } \\
\text { залу, організація свят та вечірок. }\end{array}$ \\
\hline & & 2. ЦА & $\begin{array}{l}\text { Чоловіки та жінки віком від } 16 \text { до } 40 \text { років, } \\
\text { проживають у місті. Рівень доходу від низького } \\
\text { до «вище середнього». Основний сегмент } \\
\text { споживачів - творча молодь, люди, які } \\
\text { цікавляться певним напрямом мистецтва, } \\
\text { прагнуть самореалізації, саморозвитку, нових } \\
\text { комунікаційних зв'язків. Арт-кафе відвідують у } \\
\text { свій вільний час після роботи/навчання з метою } \\
\text { завітати на певний захід (активно провести час), } \\
\text { прагнуть бути причасними до громадського, } \\
\text { суспільно-культурного життя. }\end{array}$ \\
\hline & & 3. Цінова політика & $\begin{array}{l}\text { Ціни на меню - середні, нижче середніх. Вхід на } \\
\text { різноманітні заходи, також за доступними цінами, } \\
\text { або за символічну плату (часто, безкоштовно). }\end{array}$ \\
\hline & & 4. Місце знаходження & $\begin{array}{l}\text { Арт-кафе розташовують не обов'язково в центрі } \\
\text { міста, часто на віддалених вулицях. Тяжіють, } \\
\text { також, до місця, зручного цільовій аудиторії } \\
\text { (поблизу міських парків, університетів). }\end{array}$ \\
\hline
\end{tabular}




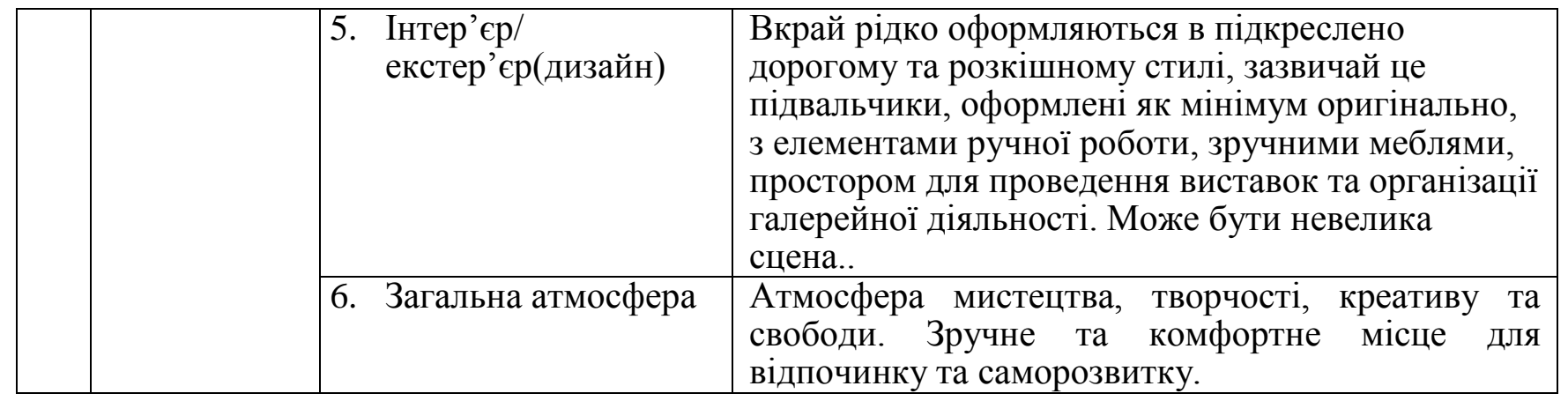

Отже, категорія арт-кафе - має свою специфіку та унікальність, в першу чергу це: арт-складова, творче спрямування, унікальність дизайну, простота, доступна цінова політика, різноспрямованість розважальної програми.

Підприємці, які працюють у даній сфері не виділяють конкретних рамок та систем, за якими має працювати арт-кафе, але існують певні принципи, наприклад арт-кафе рідко оформлюють в пишному й дорогому стилі, зазвичай розміщують у невеликих, підвальних приміщеннях, шляхом оздоблення (дизайну) створюють унікальну атмосферу закладу та послуг, які надають, таким чином утримуючи свою цільову аудиторію.

Окрема увага приділяється напряму діяльності арт-кафе, серед яких виділяють такі: музика, література, живопис, графіка, фотографія, театр, тематичність та handmade. Частіше за все, в арт-кафе об'єднують декілька таких напрямів мистецтва (змішані), які задовольняють потреби цільової аудиторії.

На рисунку приведено процентне співвідношення розповсюдженості (популярності) напрямів діяльності арт-кафе у світі та в Україні.
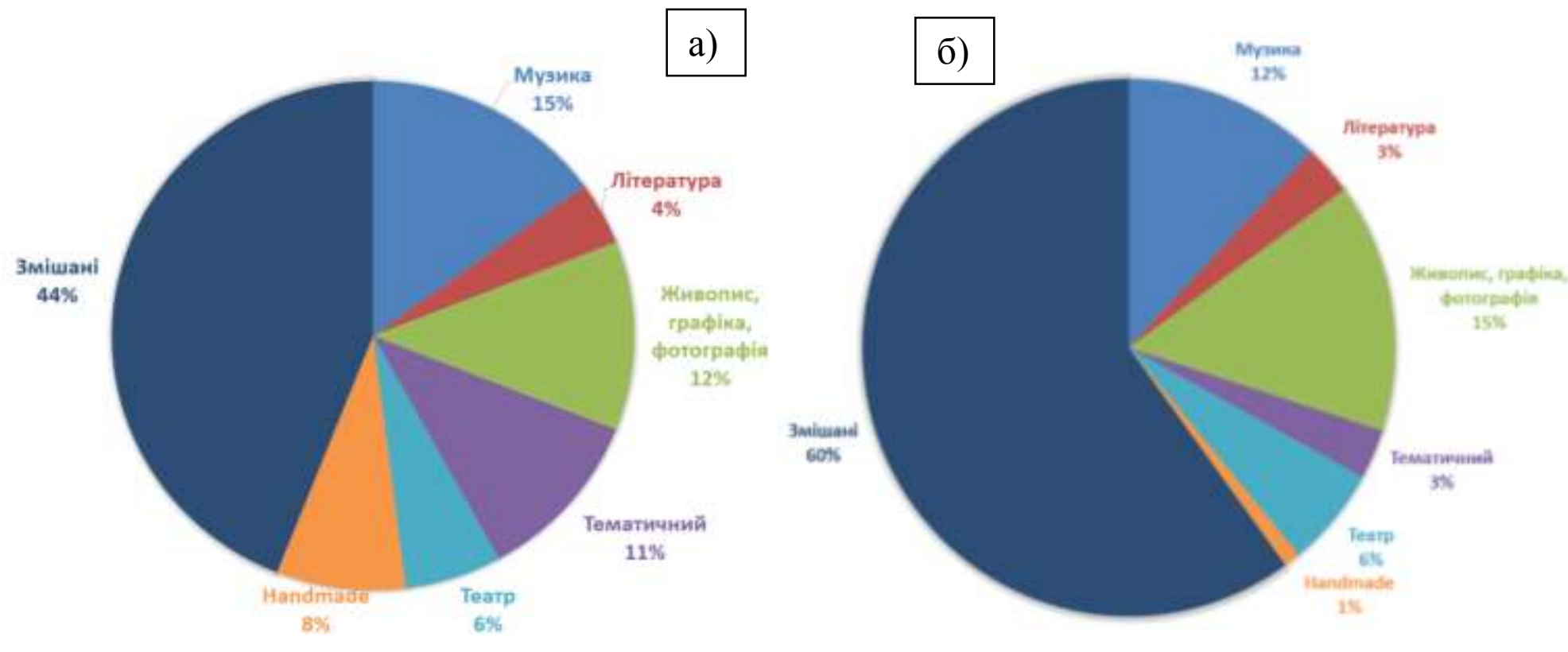

a) Напрями діяльності арт-кафе у світі

б) Напрями діяльності арт-кафе в Україні

Рисунок. Напрями діяльності арт-кафе

Далі, наведемо та розглянемо характерні «портрети» арт-кафе різних країн світу 3 метою дослідження міжнародної практики в даній сфері діяльності. 


\section{Арт-кафе США}

Арт-кафе територіально розташовані в східній частині Сполучених Штатів. Заклади даного типу концентруються в густо заселених територіях країни з високим рівнем щільності населення та переважно орієнтуються на популярні у туристичних колах містах.

Для дослідження досвіду міжнародної практики в США було обрано арткафе: «PartyArtCafe\&Studio», «Nyack» та «BrasilArtsCafe» різної територіальної локації та напряму діяльності.

\section{«PartyArtCafe\&Studio»}

Слоган: Relax, Smile\&Paint

Місце знаходження арт-кафе: PartyArtCafe\&Studio, 5000 EastMarketStreetSuite 2, Warren, Ohio 44484.

Години роботи - 11:00 - 17:00, Вт - Сб.

Офіційний веб-сайт арт-кафе: http://partyartcafe.com/

«PartyArtCafe\&Studio» знаходиться на першому поверсі торгового центру. Дане арт-кафе спеціалізується на проведенні майстер-класів, уроків 3 малювання, ручній роботі з керамікою та глиною. Цільова аудиторія доволі широка й охоплює дітей віком від 5 років до людей похилого віку.

Арт-кафе заздалегідь створює календарні заходи, на які клієнти мають можливість забронювати собі місце приблизно за тиждень (через сайт чи у телефонному режимі). Група з 8 людей, при одноразовому бронюванні, матиме знижку від закладу. Середня ціна відвідування арт-заходу для дорослого (віком від 21 року) - коштує в середньому 35\$ (ціна залежить від кількості використаних матеріалів: полотен, фарб і т.д.), для дитини - 20\$. Також, заклад під час уроків забезпечує учасників усіма необхідними матеріалами й знаряддям для роботи).

У «PartyArtCafe\&Studio» відсутня кухня та меню, про те під час заходів та уроків відвідувачам пропонують каву, чай, безалкогольні напої та десерти.

Робота арт-кафе грунтується на ідеї цікавого, веселого проведення часу за ручною роботою разом 3 друзями чи родиною. Проводяться як групові, так й індивідуальні зайняття, а також захід можна замовити через офіс кафе. Відвідати подібний арт-захід малювання на полотні чи на керамічному виробі можна не тільки вдень, але і вночі (захід «Відкриті ночі живопису»). У даному арт-кафе також можна прийти на екскурсію в галерею самого закладу.

Цінність, яку набувають відвідувачі арт-кафе - отримання позитивних емоцій, навики в ручній роботі, живе спілкування, саморозвиток особистості.

\section{«Nyack»}

Місце знаходження: 65 S Broadway, Nyack, NY, 10960, UnitedStates

Години роботи: Пн - Чт з 07:00 до 22:00; Пт-Нд з 07:00 до 01:00 (кухня до 23:00)

Офіційний веб-сайт арт-кафе: http://www.artcafenyack.com/

Арт-кафе «Nуасk» знаходиться у двоповерховому дерев'яному будинку жилого кварталу, який зовні схожий на приватний дім, про те інтер'єр та екстер'єрзакладу й літньої веранди відповідає усім критеріям об'єкту яким являється. Дане арт-кафе має дещо посередню позицію між арт-кафе, 
рестораном середнього класу та баром (позначається в оздобленні закладу, доволі широкому виборі страв та напоїв). Цільова аудиторія: чоловіки та жінки (американці та туристи) віком від 20 до 60 років. «Nyack» - комфортне та зручне місце для зустрічі та спілкування з друзями, родиною, для романтичних вечорів.

«Nyack» позиціонує себе як місце з вишуканою їжею, широким вибором органічної, свіжої кави. Власники цього закладу привезли ідею такого кафе 3 Тель-Авіву й тому в меню наявні традиційні ізраїльські рецепти. Кухня арткафе готує тільки зі натуральних інгредієнтів і переважно здорову їжу. Окрім органічної кави серед напоїв у меню є «здорові» коктейлі, пиво та вино.

У цьому американському арт-кафе проводяться фотовиставки (на території кафе працює фотограф) та вечори/ночі живої музики (розклад заходів розміщено на офіційному сайті). На сайті споживачам надається можливість придбати подарунковий сертифікат від арт-кафе (на його відвідування) (ціна від $15 \$$ до 500\$).

Цінність арт-кафе «Nyack» для споживачів даної послуги полягає у якісному відпочинку (широке меню, цікаві, творчі вечори, зручне місце для спілкування тощо), смачна їжа, соціалізації та комунікації.

\section{«BrasilArtsCafe»}

Слоган: A piece of Brasilin SantaBarbara

Місце знаходження: 1230 StateStreetSte C SantaBarbara,CA 93101

Години роботи: Пн-Нд з 09:00 до 21:00; Сб з 10:00 до 18:00

Офіційний веб-сайт арт-кафе: http://brasilartscafe.com/

Дане арт-кафе просуває культуру, історію та загальну атмосферу Бразилії в Америці через традиційну бразильську їжу, танці, мову, звичаї та мистецтво. Арт-кафе проводить заняття 3 капоейро для дітей та дорослих. Широка програма заходів кафе включає: виступи музикантів, уроки танців, флешмоби різної тематики, вечірки, карнавали, змагання 3 капоейро та інші події (тим самим кафе дотримується основної ідеї та працює для широкої цільової аудиторії). Меню кафе має сніданки, обіди та вечері, бургери, буріто, сандвічі та салати, а також напої й десерти.

«BrasilArtsCafe» - має власне приміщення 3 унікальним тематичним дизайном (яскраві жовті та зелені кольори стін, символи, знаки та елементи культури Бразилї тощо).

Унікальність арт-кафе полягає у тому, що за допомогою меню, невеликої площі закладу та особливої атмосфери - американців та туристів міста знайомлять 3 культурою цілої країни. Дане кафе являється своєрідним туристичним місцем.

Цінність для відвідувача такого арт-кафе - пізнання нового, саморозвиток, позитивні емоції, спілкування.

Загалом в США налічується близько 3000 закладів типу арт-кафе. Основними спільними рисами арт-кафе у даній країни є: конкретизація напряму діяльності арт-кафе (ручна робота, музика, етнічність тощо); доволі різке розшарування арт-кафе за класами та ціновою політикою (заклади, що працюють на ідеї благодійності, елітні кафе в престижних районах міста і т.д.). 
До характерних особливостей даного бізнесу в США можна віднести те, що більшість арт-кафе проводять активну та ефективну комунікаційну політику за своєю цільовою аудиторією.

\section{Арт-кафе Великої Британії}

Арт-кафе Великої Британії орієнтовані на великі міста (Лондон, Манчестер, Ліверпуль тощо) 3 високим рівнем щільності населення та постійним потоком туристів. Заклади, часто, інтегровані 3 виставковими центрами або галереями. Лондонські арт-кафе, часто, являються престижними туристичними місцями. Для дослідження досвіду міжнародної практики в Британії було обрано арт-кафе: «TheArtcafé», «NexusArtCafe», «EvergreenArtCafe».

\section{«TheArtcafé»}

Місце знаходження: 7 TrinitySt, Colchester CO1 1JN, GreatBritain

Години роботи: Пн-Нд - 09:00 -19:00

Офіційний веб-сайт арт-кафе: http://www.islandartcafe.co.uk/index.html

«TheArtcafé» було засноване у 2003 році чоловіком (художник за професією) та дружиною (шеф-кухарем) 3 метою інтегрувати в одному місці напрямки діяльності, які цікавлять їх та зацікавити цим потенційну цільову аудиторію. За час існування даного арт-кафе його власники зуміли розшири мережу, створивши ще два подібних заклади за схожою бізнес-концепцією. Їжа готується 3 продуктів, що закуповуються у локальних виробників. Меню змінюється в залежності від сезонності тих чи інших місцевих інгредієнтів. Більшу частину відходів намагаються переробити екологічно-чистим шляхом. Меню арт-кафе базується на традиційних англійських стравах (булочки 3 різними начинками (беконом, кленовим сиропом, копченим лососем, яєчнею тощо), різноманітні бутерброди, домашня свіжа випічка за старовинними рецептами, широкий асортимент чаю та кави. Арт-кафе має декілька просторих зал, оформлених у світлих кольорах з дерев'яними меблями, а також літню веранду. Кафе пропонує відвідувачам пізнавати роботи як відомих майстрів, так і художників-початківців (картини, гравюри, керамічні вироби, фотографії, ювелірні вироби, колекції листівок тощо).

Головна ціль заснування такого арт-кафе (як описують його власники) створення виставкового простору в жвавому середовищі кафе, де мистецтво подається вільно та невимушено. Галерея арт-кафе весь час у пошуку творців, які б хотіли донести свої роботи людям. Додатковою особливістю є меню здорової їжі, свіжа випічка та еко-спрямованість закладу.

Цінністю для відвідувача даного кафе є: саморозвиток (пізнання нового), спілкування та комунікації (цікаве проведення часу), тамування голоду екологічно-чистою їжею.

\section{«NexusArtCafe»}

Місце знаходження: 2 DaleSt,Manchester M1 1JW, GreatBritain

Години роботи: Пн-Нд - 11:00 - 18:30; Сб - 12:00 - 17:30

Офіційний веб-сайт арт-кафе: http://nexusartcafe.com/

«NexusArtCafe» - творчий простір у центрі Манчестера, мета якого створити спільноту на основі етносу, поваги та гостинності, грунтуючись на 
трьох китах: творчості, духовності та спільної общини. Меню кафе складається iз різного типу салатів, сандвічів, тостів, страв з м’яса та картоплі, напоїв (чаї, соки та кави). Дане кафе розміщується на першому поверсі жилого будинку 3 оригінальною вітриною, оформленою відповідно до поточної виставки (фотографій, картин тощо). Має просторий зал, оформлений меблями різного типу та виду, що створює незвичайну атмосферу. Заклад пропонує зацікавленим приймати участь у ряді духовних заходів (зустрічі християнської громади в кафе два рази на тиждень).

«NexusArtCafe» $\epsilon$ виключно безалкогольним місцем, де регулярно проводяться заходи націлені на різні типи споживачів (музичні виступи, виставки, концерти i т.д). Дане арт-кафе кожен квартал проводить набір волонтерів для допомоги в кафе протягом декількох годин на тиждень (на кухні, в залі чи під час заходів).

Цінність арт-кафе для споживачів такої послуги полягає у позитивному проведенні часу, якісному відпочинку, можливістю у незвичайному місці пізнати незвичайні роботи сучасних митців.

«EvergreenArtCafe», слоган: Funart, Greatcoffee

Місце знаходження: 30 SheafSt,Daventry NN11 4AB, GreatBritain

Години роботи: Пн-Сб з 09:00 до 17:30

Офіційний веб-сайт арт-кафе: http://www.evergreenartcafe.co.uk/

«EvergreenArtCafe» розташоване на першому поверсі житлової будівлі й яскраво вирізняється зеленим дизайном своїх вітрин та входу. Кафе утворено декількома просторими залами, стіни яких заповнені картинами, також є літня веранда. Дане арт-кафе позиціонує себе як незалежну галерею й співпрацює 3 провідними художніми видавництвами. Меню кафе складається з гарячих та холодних страв, широкий вибір напоїв.

«EvergreenArtCafe» має декілька нестандартних для арт-кафе послуг: доставка їжі (замовлення по телефону чи он-лайн на сайті). Так як філософія арт-кафе - доступне мистецтво для кожного, то заклад співпрацює 3 HitachiCapital (UK) PLC (одним 3 найбільших постачальників у Великобританії безвідсоткових кредитів), саме тому клієнти кафе можуть придбати екземпляри робіт 3 виставки на безвідсоткових умовах. Ще однією послугою $\epsilon$ консультування - якщо споживач не може визначитись з об'єктом мистецтва, який бажає придбати, то зв’язується з командою арт-кафе, і додому клієнта приїде працівник з екземплярами картин і допоможе обрати найкращий варіант. Також, за допомогою сайту, споживач може обрати об'єкт мистецтва та замовити його не відвідуючи галерею, при чому доставка по Британії безкоштовна. У кафе можна замовити приватну вечірку в окремому залі.

«EvergreenArtCafe» несе цінність у своїй особливій атмосфері, комфортному часі проведення, саморозвитку та пізнанні нового.

Загальними, об’єднуючим факторами для арт-кафе Великої Британії (яких налічується близько 800) є їхня орієнтація на розвиток культури, пізнання мистецтва, організація соціальних заходів та подій. Акцент бізнесмени роблять,частіше, на мистецтві певного напряму, виступають у ролі галерей та невеликомасштабних центрів культури. До характерних особливостей даного 
бізнесу в Великий Британії слід віднести широкий спектр послуг, які надають арт-кафе (доставка їжі, сувенірів та товарів, просування письменників, музикантів тощо).

\section{Арт-кафе Нідерландів}

Арт-кафе Нідерландів орієнтовані, в більшій мірі, на своїх споживачів, а тому даний бізнес розвивається не лише у великих містах країни, але й у містах 3 невеликою кількістю населення. Для дослідження досвіду міжнародної практики Нідерландів було обрано арт-кафе різної спрямованості: «CloudArtCafe», «ArtCaféSam-Sam», «CakeArtStudio».

\section{«CloudArtCafe»}

Місце знаходження: Prinsengracht 276, 1016 HJ, Amsterdam

Години роботи: Пн-Пт - 08:00-18:00; Сб - 09:00-18:00; Нд - 10:00 -17:00

Офіційний веб-сайт арт-кафе: http://www.cloudartcoffee.nl/

Aрт-кафе «Cloud» являє собою просторе приміщення, зі скляною вітриною та входом. Зал облаштований простими меблями: стільцями та великим столами із деревини. Білі стіни - i $\epsilon$ тим арт-простором, де презентують картини, фотографії та інші елементи мистецтва. Атмосфера закладу, навіть, більше музею чи галереї, а ніж кафе. Меню арт-кафе складається із гарячих, холодних напоїв, кави, чаю та десертів.

«Cloud» має CloudArtShop - магазин, в якому можна придбати цікаві та оригінальні предмети мистецтва (скульптури, фотографії чи картини, ціни від 200 до 1500 євро).

Дане арт-кафе є своєрідним популярним туристичним місцем і кожен турист та путівник прагне потрапити в це кафе. Також, «Cloud» може бути комфортним місцем для віддаленої роботи. Цінність відвідувачі знаходять у пізнанні нового та цікавого мистецтва, особливій атмосфері для живого спілкування, престижності та популярності закладу.

\section{«ArtCaféSam-Sam»}

Місце знаходження: VanKinsbergenstraat 177311 BL Apeldoorn

Офіційний веб-сайт арт-кафе: http://www.artcafesamsam.nl/index.html

Кафе знаходиться у будівлі спроектованій архітектором Chris Wegerif. Кожну четверту неділю в арт-кафе відкривається нова експозиція за урочистої манери, що включає живу музику та закуски. У «ArtCaféSam-Sam» кожного дня виступи 3 живою музикою різних гуртів (Lex\&Friends, TheOldBridge, Jocomo, Bizarcordeenveleanderen тощо). Також, один раз на тиждень, щоп'ятниці, проходить JamSessie - музичний концерт, в якому кожен бажаючий може прийняти участь. Кілька раз на тиждень в арт-кафе проходять уроки сальси з професійним тренером. Зал кафе можна забронювати для проведення приватного заходу. Меню арт-кафе складають закуски та напої.

Регулярне проведення виставок, музичних концертів (як відомих музикантів, так і початківців), виступи гуртів, незвичайна атмосфера, дизайн закладу- зацікавлюють місцевих жителів та туристів.

Цінність, відвідувачі арт-кафе, знаходять у цікавому проведенні часу, емоційному піднятті настрою, психологічній розгрузці, саморозвитку.

\section{CakeArtStudio}


Місце знаходження: Zeestraat 44, 1942 AR Beverwijk

Офіційний веб-сайт арт-кафе: http://www.cake-art-studio.nl/en/

Арт-студія має особливу специфіку - спеціалізується на виготовленні домашньої випічки, тістечок, тортів та інших солодощів. Мистецтво та арт спрямування закладу також має тісний зв'язок з кулінарією. Кафе виготовляє солодощі та десерти, які продає в кафе та робить на замовлення. В арт-студії проводять захід під назвою WeekendCollege від проекту WeekendTuner. Тематика лекцій з різних напрямків мистецтва (як розуміти живопис, «читати» картини і т.д.), а також працює школа натюрморту. В меню окрім солодощів $\epsilon$ чай та кава. Кафе утворено з однієї невеликої зали.

Специфіка арт-студії та концепція - особливість даного закладу. Кожного місяця поряд з будівлею студії проводять ярмарок продукції кафе.

Саморозвиток та отримання нових навичок за допомогою лекцій та уроків, приємний час проведення, живе спілкування, особлива продукція.

Загальна кількість закладів даної категорії в Нідерландах сягає близько 400. Основними спільними рисами арт-кафе даної країни є: поліфункціональність - заклади працюють в якості кафе, галерей, виставкових центрів, магазинів, громадських місць відпочинку та роботи (саме в цьому $\epsilon$ фактор їх ринкового успіху)

\section{Арт-кафе Австралії}

Арт-кафе Австралії розташовані на східній та південній частині узбережжя материка й це спричинено: вищим рівнем густоти населення в даних регіонах, високим потоком туристів, розвитком курортних міст. Для дослідження досвіду міжнародної практики в Австралії було обрано арт-кафе різної спрямованості: «Oceanartcafe\&gallery», «TheCanvasArtCafe», «UnitedCansStreetArtCafe».

«Oceanartcafe\&gallery» - coolangatta, goldcoast

Місце знаходження: 110 MarineParade, ReflectionsTowerTwo, Coolangatta 4225, Australia

Години роботи: Пн-Нд з 05:30 до 17:30

Офіційний веб-сайт арт-кафе: http://oceanartgallery.com.au/

«Oceanartcafe\&gallery» - місце для шанувальників серфінгу. Кафегалерея-магазин - так скоріше можна охарактеризувати даний заклад. Кафе пропонує відвідати меню здорових сніданків та обідів (так як кафе працює до 17:00), холодні (соки та коктейлі) та гарячі напої (чай та каву). Галерея являє собою виставки місцевих фотографів-серфінгістів (Peter 'Joli' Wilson, WillemUngermann, AsherKingandSeanScott). Фотографії можна купувати як безпосередньо в галереї, так і за допомогою сайту (усі роботи наявні в електронному форматі для зручного перегляду та вибору). Товари магазину арт-кафе: починаючи від книг, фірмових футболок, дисків, сувенірів закінчуючи класичними дошками для серфінгістів. Арт-кафе розміщається в невеликому залі (де знаходиться одночасно і виставка, і товари магазину), поряд зі входом розміщені столики для відвідувачів.

Особливістю «Oceanartcafe\&gallery» $€$ його місце розташування (біля океану та пляжів). Заклад - тематичний і має конкретну цільову аудиторію, 
приваблює не лише професійних серфінгістів та любителів цього виду спорту, а також місцевих жителів, туристів.

Цінність арт-кафе «Oceanartcafe\&gallery» у здоровій, австралійській їі, особливому місці розташуванні, багатофункціональність закладу.

«TheCanvasArtCafe»

Місце знаходження: 73 IpswichroadWoolloongabba, QLD, 4102Australia

Години роботи: Пн-Пт з 06:00 до 14:00, Сб з 10:00 до 15:00.

Офіційний веб-сайт арт-кафе: http://thecanvasartcafe.com.au/index.html

«TheCanvasArtCafe» розташоване на одній із головних вулиць міста Woolloongabba, поряд розміщені також Арт-Фабрика та галерея абстрактного мистецтва (AbstractArtShed), які відносять також до арт-кафе. Кафе розміщається у невеликому вантажному контейнері, але раціонально та ефективно обладнане як звичайне кафе. «TheCanvasArtCafe» - новітній тип авто-кафе. Заклад було створено командою ентузіастів, які люблять каву та мистецтво. Меню закладу складає «здорова» їжа та декілька видів кави й чаю.

Арт-кафе «TheCanvasArtCafe» - нестандартне кафе, так яке розміщається в вантажному контейнері, в цьомуйого унікальність. Асортимент меню можна замовити та отримати службою доставки арт-кафе. «TheCanvasArtFactory» арт-фабрика, окремий заклад, що співпрацює 3 кафе й спеціалізується на виготовленні оригінальних принтів (настінні картини, графіки, полотна для вікон тощо) (є можливість завантажити власне зображення або обрати 3 існуючого архіву).

Цінність цього арт-кафе для його відвідувачів у отриманні позитивних емоцій, спілкуванні в нестандартному місці, оригінальної обстановки закладу.

«UnitedCansStreetArtCafe»

Місце знаходження: 80 PuntRd,WindsorMelbourne,VIC, Australia

Години роботи: Пн-Нд з 08:00 до 01:00

Офіційний веб-сайт арт-кафе: http://unitedcanscafe.com.au/

«UnitedCansStreetArtCafe» засноване сімейною парою. Заклад розміщується на периферійній вулиці міста. Дане кафе спеціалізується на французькій кухні (особливо сандвічах та багетах). Кава - найпопулярніший напій кафе. Їжу та напої можна також замовляти он-лайн з доставкою.

«UnitedCansStreetArtCafe» відоме своїми графіті в екстер’єрі та інтер’єрі. Полиці кафе заставлені балончиками для малювання різних кольорів та розмірів, які також можна придбати.

«Атмосферність» закладу, тематична кухня, спілкування: основні цінності для цільової аудиторії.

В Австралії нараховується близько 800 арт-кафе, спільними рисами для яких є: тематична спрямованість закладів; об'єднання кафе 3 магазинами та виставковими центрами; просування кухні «здорового харчування». Основним фактором успіху на ринку Австралії закладів арт-кафе, слід зазначити, загалом доступну цінову політику як для місцевих жителів, так і для туристів країни.

Узагальнюючи результати проведеного дослідження міжнародного досвіду арт-кафе зазначимо наступне: 
1) Арт-кафе - категорія закладів, які набирають свого розвитку на всіх континентах світу, так як існує сталий сегмент цільової аудиторії, споживачів зацікавлених в послугах саме такого типу кафе.

2) У кожній країні арт-кафе має свої особливості та специфіку (заклади, скоріше, в одиничному екземплярі, індивідуальні в кожному місті), про те концепція просування та донесення людям мистецтва в різних його проявах, активне соціально-культурне життя - зберігається, як традиційна ідея.

3) Арт-кафе - компонує в своїй діяльності більше, ніж поєднання мистецтва (і творчості) з послугою громадського харчування (кафе), може паралельно функціонувати як магазин (з відповідною продукцією), культурний центр чи галерея і т.д., що лише додає споживачам додаткової цінності від користування послугами такого закладу.

4) Метою традиційного закладу категорії арт-кафе $\epsilon$ створення своєрідної касти, об'єднання молоді, активних людей, просвіта в розрізі мистецтва, стимулювання людей до розвитку та самопізнання.

5) При створенні закладу даного типу, слід орієнтуватись на рівень густоти населення, масштаби міста, популярні туристичні зони.

Також, вивчення міжнародного досвіду закладів формату арт-кафе дозволило вивести своєрідну формулу - концепцію успішного арт-кафе. Вона має наступний вигляд:

$$
\text { Apm-кафе }=I+M+A C+M u
$$

Арт-кафе = оригінальна ідея + місие розташування + арт-складова + меню

Розкриємо детальніше зазначені складові формули:

Оригінальна ідея (I) включає в себе: назву та логотип, слоган; філософію та ідею закладу; формат закладу тощо.

Місие розташування (M): безпосередньо місце, де знаходиться заклад (підвал, дах, вантажний кузов і т.д.); екстер'єр та інтер'єр, загальна атмосфера, яку створює дизайн.

Арт-складова (AC) може включати: галереї, виставки, спеціалізація на ручній роботі, музика, література тощо. До арт-складової може входити як один iз напрямів, так і декілька, головне ефективне їх поєднання та наявність відповідних потреб щодо цих елементів у споживачів послуги. Ця складова потребує високої гнучкості та адаптації.

Меню $(M н):$ може бути 3 широким або мінімальним асортиментом їжі та напоїв: тематичним - їжею певної субкультури (сироїдіння, здорова їжа) або 3 традиційною кухнею певної країни.

Робота зданою формулою може бути наступна: кожному елементу даної формули можна дати значення за шкалою від 1 до 5, яке означитиме оцінку рівня того чи іншого елементу ( 1 - дуже погано, 2 - погано, 3 - задовільно, 4 добре, 5 - дуже добре). Оцінюючи реалізацію і роботу закладу максимально можливо набрати 20 балів і відповідно чим вищий бал, тим краще. 
Для того, щоб отримане значення за формулою не було суб’єктивним (якщо зацікавлена особа, або навіть сам власник кафе виставляє бали своєму закладу), необхідно провести опитування серед існуючих клієнтів арт-кафе за всіма елементами формули із завданням виставити бал від 1 до 5, таким чином можна отримати об'єктивні оцінки i, відповідно, зрозуміти подальші напрямки вдосконалення.

Також результати виконаного дослідження дозволяють запропонувати наступні рекомендації з проектування та реалізації закладів типу арт-кафе.

1) Створення офіційного сайту арт-кафе в мережі Internet, відмітка геолокації та адреси на ресурcaxGoogle (а також фото, опис) - зробить заклад більш доступним як для місцевих відвідувачів, так і для туристів.

2) Якісне ведення сторінок в соціальних мережах (Fb,Instagram тощо) - додатковий потужний інструмент комунікацій зі своєю цільовою аудиторією.

3) Важливо конкретно визначати (за допомогою досліджень, наприклад) потреби та цінності цільової аудиторії 3 метою вибору оптимального напряму діяльності закладу (художній, театральний, змішаний тощо).

4) Партнерство 3 галереями, виставковими центрами, самостійними творчими клубами та ін. - відкриває перспективи розвитку та росту закладу без масштабних фінансових витрат.

5) Унікальний дизайн (екстер'єр/інтер'єр) та оформлення арт-кафе сильна сторона даного бізнесу, яка відображає суть «арт» закладу, оскілки перше, на що звертають увагу споживачі; створена атмосфера спонукає клієнтів відвідувати заклад.

6) Додаткові послуги та багатофункціональність закладу дозволяють реалізувати додаткові цінності для клієнтів та заробіток для бізнесу. Це можуть бути сувенірні магазини, доставка їжі тощо.

Висновки. Дослідження міжнародної практики дозволило покращити розуміння сучасної ідеї, філософії та особливостей характерних для закладів арт-кафе, дало змогу визначити фактори ринкового успіху закладів даного типу, запропонувати рекомендації 3 адаптації закордонного досвіду у вітчизняну практику, визначити формулу створення концепції успішного закладу, надати методичні рекомендації щодо проектування, реалізації та відповідності ринковим умовам закладів формату арт-кафе.

Узагальнюючи світовий досвід можна зазначити. що арт-кафе зазвичай невеликі за площею заклади й не обов'язково розташовані в місцях 3 великим потоком людей. Оформлення та дизайн - створюють необхідну атмосферу, яка і $\epsilon$ основною цінністю, якої шукають відвідувачі таких закладів. Арт (мистецтво) - поняття широке й необов'язково передбачає в кафе наявність галереї чи художньої виставки або інших заходів такого роду (наприклад арт-кафе в Австралії не організовують музичних чи творчих вечорів, але все-одно залишаються в статусі арт-кафе за інших факторів) та заклади такого типу можуть мати певну тематику (серфінг або графіті у арт-кафе Австралії, бразильська культура в кафе США). Меню кафе даної категорії можуть бути найрізноманітнішими від мінімуму: кави та десертів, до повноцінних сніданків 
та обідів (відповідно це $є$ фактором, від якого залежить цінова політика). Меню зазвичай має свою особливість: спеціалізація на якісній, відбірній каві або на свіжій випічці чи акцент на еко-їжі, широкому асортименті страв у меню тощо.

Також, характерною тенденцією $\epsilon$ наявність в меню «здорової», органічної їжі, корисних напоїв. Власники піклуються про екологічність їжі, переробку відходів.

Частіше за все, арт-кафе мають додаткові послуги: невеликі магазини, майстерні, виставки, на яких можна придбати експонати, замовлення та доставка їжа (покупок) он-лайн, послуга оренди залу, організація свят тощо. Заходи, що організовують та проводять в арт-кафе - найрізноманітніші: виступи музикантів, виставки фото чи картин, літературні й творчі вечори, тренінги та майстер-класи, уроки ручної роботи і т.д. Цінова політика закладів спирається на ідею доступності і необтяжливості для своїх цільових аудиторій. Це стосується i меню i заходів закладу, які часто бувають взагалі безкоштовними.

\section{Література:}

1. Аносова М.М. Організація виробництва на підприємствах громадського харчування[Текст] / М.М. Аносова, Л.С. Кучер. - М., 2003. - 480 с.

2. Кафе // Энциклопедический словарь Брокгауза и Ефрона : в 86 т. (82 т. И 4 доп.). - спб., $1890-1907$.

3. "A Restaurant Timeline", cuisinenet Diner's Digest, retrieved April 28, 2009

4. Пикалев А. Як збільшити дохід ресторану, бару, кафе. - 4-е вид., Доп. [Текст] / А. Пикалев, А. Маєвська. - спб.: Бізнес-преса, 2004. - 168c.

5. Усов В.В. Организация производства и обслуживания на предприятиях общественного питания. - М: Академия, 2010 г. - 190с.

6. Drucker, Peter F., "The Practice of Management", 1954. ISBN 0-06-011095-3. Російською: Питер Ф. Друкер "Практика менеджмента". — М.: Вильямс, 2009. — С. 400. — ISBN 07506-4393-5 